\title{
DETERMINATION OF TOTAL NITROGEN MATTER AND PROTEIN CHANGES DURING RIPENING OF BIENO CHEESE
}

\author{
Gordana Dimitrovska ${ }^{* 1}{ }^{\circledR}$, Sonja Srbinovska ${ }^{2}$, Elena Joshevska ${ }^{1}$, Borche \\ Makarijoski ${ }^{1}$ \\ ${ }^{* 1}$ Department of Food Technology, University "St. Kliment Ohridski"- Bitola, Faculty of \\ Biotechnical Sciences, North Macedonia \\ 2 Department of Animal Products Technology, University "St. Cyril and Methodius"- Skopje, \\ Faculty of Agricultural Sciences and Food, North Macedonia
}

DOI: https://doi.org/10.29121/granthaalayah.v9.i2.2021.3289

Article Type: Research Article

Article Citation: Gordana Dimitrovska, Sonja Srbinovska, Elena Joshevska, and Borche Makarijoski. (2021).

DETERMINATION OF TOTAL NITROGEN MATTER AND PROTEIN CHANGES DURING RIPENING OF BIENO CHEESE. International Journal of Research GRANTHAALAYAH, 9(2), 32-37. https://doi.org/10.29121/granthaa layah.v9.i2.2021.3289

Received Date: 25 January 2021

Accepted Date: 18 February 2021

Keywords:

Cheese

Curd

Ripening

Quality

\begin{abstract}
The main purpose of this research was to determine the dynamic of total nitrogen matter and protein changes during ripening period of three kinds of indigenous Bieno cheese (A, B and C) in the region of Mariovo. The three kinds of Bieno cheese were produced with different traditional technologies. The cheese samples were analyzed for total nitrogen matter and protein during ripening process in five time intervals (in curd, after ripening, after salting, at 20-th day, at 45th day). The concentration of total nitrogen matter in examined Bieno cheese samples was between $3.98 \pm 0.06 \%$ to $4.16 \pm 0.15 \%$ and the concentration of protein in examined Bieno cheese samples was between $25.48 \pm 0.49 \%$ to $26.53 \pm 0.93 \%$. No significant differences in total nitrogen matter and protein concentration for $\mathrm{p}<0.05$ and $\mathrm{p}<0.01$ were determined. Proteolysis is affected by the type and amount of enzyme, the temperature during the ripening of the cheese, the length of ripening and the activity of the enzymes. The technological process of production, in essence, greatly affects the dynamics and breakdown of proteins, which is confirmed by our research.
\end{abstract}

\section{INTRODUCTION}

The southwestern part of our country is found to be tremendously rich in a variety of dairy products. Most of them are produced industrially, and some of them are produced in autochthonous, which are usually related to the area of production. Those products are typical for rural households and they are distinguished with unequal and non-standardized quality. Despite such conditions for the production of indigenous products, especially in regard of cheese production, yet they can develop modern dairy products that can conquer the market and enrich the range of production (Dozet, 1974).

Bieno cheese belongs to the group of indigenous types of cheese whose production dates back since ancient times. It belongs to the group of hard cheeses with a very salty taste, firm consistency and light yellow color. This

(C) 2021 The Author(s). This is an open access article distributed under the terms of the Creative Commons Attribution License, which permits unrestricted use, distribution, and reproduction in any medium, provided the original author and source are credited. 
type of cheese has been previously prepared from skimmed sheep milk, but due to the deficiency of sheep milk, nowadays its production is widespread in other areas and is produced from a mixture of sheep and cow milk, only cow milk, as well as a mixture of sheep and goat milk.

This indigenous product is quite specific due to the fact that it matures and is stored similarly as the cheeses from the group of sour-brine cheeses. When it comes to cheese ripening, it is important to emphasize that it refers to a complex process that involves breakdown of the coagulum by proteolysis, lipolysis and other enzyme-catalyzed reactions which, in turn, result in changes in taste and texture which is typical for various types of cheese (Mastrigt et al., 2018). Proteins, fats and sugars change during the ripening process (Cvetanović et al., 2008). Proteolysis of proteins during the ripening process has an essential influence on the formation of the consistency, texture, appearance, taste and aroma of cheeses (Baltadzieva, 1993).

The goal of the paper is to examine the dynamics of nitrogenous substances during separate stages of ripening of three varieties of Bieno cheese produced by indigenous technology in Mariovo region in our country.

\section{MATERIALS AND METHODS}

\section{Materials}

The production of Bieno cheese was made in three different locations in the Mariovo region, each of them owing to a special production technology $(\mathrm{A}, \mathrm{B}$, and $\mathrm{C}$ ). The technological procedure includes: filtering the milk and transporting it to the duplicator where reheating to a temperature of $35-37^{\circ} \mathrm{C}$ has been performed. Then, a curdling with final coagulation of 45-60 minutes was performed. When the coagulum has become firm enough, it was processed for 2-5 min thus acquiring a grainy structure, and left to rest for 10-15 minutes. This was followed by beating again for 2-5 minutes and obtaining curds in the size of a grain of corn. There was a resting time in order to separate the whey, and at the end $2 / 3$ of the whey was removed with a pump. In the next phase, the cheese mass was steamed for 30 minutes, then the curd was separated at the bottom of the cheese bathtub, followed by cutting, kneading, and shaping of the cheese dough. The shaped cheese dough in a form of a ball was left to drain, i.e. selfpressing for a period of 16-18 hours. The self-pressing was left up until the next day. Further on followed the phase of dry ripening of the cheese. The formed blocks are placed in wooden molds, on wooden shelves in a maturation chamber, where $t=26-280^{\circ} \mathrm{C}$ and the relative humidity is $90-95 \%$, for a period of $5-6$ days, during which the cheese blocks get a wax-yellow color. After the completion of the ripening period of the cheese blocks, they are cut along their entire length into 5-6 cm strips. Dry salting with coarse sea salt begins after 1-2 days, and subsequently they are placed in bins while $20-22 \%$ salt is added. The cheese is stored at $t=16-180^{\circ} \mathrm{C}$ in a room where it is further matured for up to 45 days and finally stored.

The operations of this production technology are the same as for the produced Bieno cheese A, B and C, however, there are differences in the used rennet. Bieno cheese from the production series A is produced in industrial conditions using chymosin - cheese powder, CHY-MAX with an intensity of $2080 \mathrm{imcv} / \mathrm{g}$, while the production series $\mathrm{B}, \mathrm{C}$ are produced in two different individual households with an indigenous technology applied, using microbiological rennet - "Kvasko" with an intensity of 1: 5000 in order to determine the content of total nitrogenous substances and total proteins from the samples of cheese from the production series A, B and C, the following dynamics of the ripening process was performed:

- Curd sampled after ripening of 5-6 days;

- After dry salting;

- At the 20-th day in brine;

- After the 45th day in brine.

\section{Methods}

The examination of total nitrogen content was performed according to the Kjeldahl method, in accordance with the (AOAC, 1995) standard;

Soluble nitrogen content was performed by the Van Sluke method.

In order to obtain results that could be representative, valid, and statistically processed with a sophisticated statistical data processing package, five replicates have been carried out. 


\section{RESULTS AND DISCUSSIONS}

In the sequence of changes that occur in cheese during ripening, the changes in proteins and their breakdown products appear as the most significant. The extent and depth of proteolytic changes are closely related to cheesemaking technology, ripening conditions, and microbial activity. These changes are specific for certain types of cheese and play a crucial role in the formation of sensory characteristics, consistency and other rheological characteristics of cheeses (Jovanovic et al., 2007). The results of the total nitrogenous substances are presented in Table 1 and Figure 1 where the dynamics in different stages of ripening of the three production series of Bieno cheese (A, B and C) are shown.

Table 1: Dynamics of the content of total nitrogenous substances in Bieno cheese

\begin{tabular}{|c|c|c|c|c|c|c|c|c|c|c|c|c|c|c|c|}
\hline & \multicolumn{5}{|c|}{ Cheese Series A } & \multicolumn{5}{|c|}{ Cheese Series B } & \multicolumn{5}{|c|}{ Cheese Series C } \\
\hline & $\bar{x}$ & $\begin{array}{c}\mathrm{mi} \\
\mathrm{n}\end{array}$ & $\begin{array}{c}\mathrm{ma} \\
\mathrm{x}\end{array}$ & $\mathrm{Sd}$ & $\mathrm{Cv}$ & $\bar{x}$ & $\begin{array}{c}\mathrm{mi} \\
\mathrm{n}\end{array}$ & $\begin{array}{c}\mathrm{ma} \\
\mathrm{x}\end{array}$ & $\mathrm{Sd}$ & $\mathrm{Cv}$ & $\bar{x}$ & $\begin{array}{c}\mathrm{mi} \\
\mathrm{n}\end{array}$ & $\begin{array}{c}\mathrm{ma} \\
\mathrm{x}\end{array}$ & $\mathrm{Sd}$ & $\mathrm{Cv}$ \\
\hline Curd & $\begin{array}{c}3,44 \pm 0 . \\
28\end{array}$ & $\begin{array}{c}3,0 \\
1\end{array}$ & $\begin{array}{c}3,9 \\
0\end{array}$ & $\begin{array}{c}0,3 \\
5\end{array}$ & $\begin{array}{c}10,1 \\
2\end{array}$ & $\begin{array}{c}3,19 \pm 0 \\
09\end{array}$ & $\begin{array}{c}3,0 \\
6\end{array}$ & $\begin{array}{c}3,3 \\
4\end{array}$ & $\begin{array}{c}0,1 \\
1\end{array}$ & $\begin{array}{c}3,4 \\
8\end{array}$ & $\begin{array}{c}3,34 \pm 0 \\
17\end{array}$ & $\begin{array}{c}3,0 \\
1\end{array}$ & $\begin{array}{c}3,6 \\
6\end{array}$ & $\begin{array}{c}0,2 \\
4\end{array}$ & 7,26 \\
\hline $\begin{array}{c}\text { After } \\
\text { ripening }\end{array}$ & $\begin{array}{c}3,77 \pm 0 \\
23\end{array}$ & $\begin{array}{c}3,3 \\
5 \\
\end{array}$ & $\begin{array}{c}4,0 \\
7 \\
\end{array}$ & $\begin{array}{c}0,2 \\
9 \\
\end{array}$ & 7,55 & $\begin{array}{c}4,19 \pm 0 \\
05\end{array}$ & $\begin{array}{c}4,1 \\
0\end{array}$ & $\begin{array}{c}4,2 \\
6 \\
\end{array}$ & $\begin{array}{c}0,0 \\
6 \\
\end{array}$ & $\begin{array}{c}1,4 \\
6 \\
\end{array}$ & $\begin{array}{c}3,74 \pm 0 \\
33\end{array}$ & $\begin{array}{c}3,3 \\
5\end{array}$ & $\begin{array}{c}4,1 \\
5\end{array}$ & $\begin{array}{c}0,3 \\
9\end{array}$ & $\begin{array}{c}10,3 \\
4\end{array}$ \\
\hline $\begin{array}{c}\text { After } \\
\text { salting }\end{array}$ & $\begin{array}{c}3,93 \pm 0 . \\
16\end{array}$ & $\begin{array}{c}3,7 \\
0\end{array}$ & $\begin{array}{c}4,2 \\
7 \\
\end{array}$ & $\begin{array}{c}0,2 \\
2 \\
\end{array}$ & 5,63 & $\begin{array}{c}4,58 \pm 0 \\
12\end{array}$ & $\begin{array}{c}4,4 \\
5 \\
\end{array}$ & $\begin{array}{c}4,8 \\
9\end{array}$ & $\begin{array}{c}0,1 \\
8\end{array}$ & $\begin{array}{c}3,8 \\
5\end{array}$ & $\begin{array}{c}4,17 \pm 0 \\
09\end{array}$ & $\begin{array}{c}4,0 \\
5\end{array}$ & $\begin{array}{c}4,3 \\
4 \\
\end{array}$ & $\begin{array}{c}0,1 \\
2 \\
\end{array}$ & 2,78 \\
\hline 20-th day & $\begin{array}{c}4,11 \pm 0 . \\
09\end{array}$ & $\begin{array}{c}3,9 \\
5\end{array}$ & $\begin{array}{c}4,2 \\
1\end{array}$ & $\begin{array}{c}0,1 \\
1\end{array}$ & 2,71 & $\begin{array}{c}4,48 \pm 0 \\
09\end{array}$ & $\begin{array}{c}4,3 \\
8\end{array}$ & $\begin{array}{c}4,6 \\
3\end{array}$ & $\begin{array}{c}0,1 \\
1\end{array}$ & $\begin{array}{c}2,4 \\
3\end{array}$ & $\begin{array}{c}4,20 \pm 0 \\
02\end{array}$ & $\begin{array}{c}4,1 \\
6\end{array}$ & $\begin{array}{c}4,2 \\
4\end{array}$ & $\begin{array}{c}0,0 \\
3\end{array}$ & 0,69 \\
\hline 45-th day & $\begin{array}{c}4,16 \pm 0 \\
15\end{array}$ & $\begin{array}{c}3,9 \\
6\end{array}$ & $\begin{array}{c}4,4 \\
4\end{array}$ & $\begin{array}{c}0,1 \\
9\end{array}$ & 4,62 & $\begin{array}{c}4,11 \pm 0 \\
12\end{array}$ & $\begin{array}{c}3,9 \\
6 \\
\end{array}$ & $\begin{array}{c}4,3 \\
0\end{array}$ & $\begin{array}{c}0,1 \\
5\end{array}$ & $\begin{array}{c}3,5 \\
9\end{array}$ & $\begin{array}{c}3,98 \pm 0 \\
06\end{array}$ & $\begin{array}{c}3,9 \\
0\end{array}$ & $\begin{array}{c}4,0 \\
9\end{array}$ & $\begin{array}{c}0,0 \\
8\end{array}$ & 1,97 \\
\hline
\end{tabular}

$\mathrm{F}_{0,05}=3,88 \mathrm{p}<0,05$

$\mathrm{F}_{0,01}=6,93 \mathrm{p}<0,01$

From the results expressed in table 1 it can be perceived that the average values of the total nitrogenous substances in the curds are: $3.44 \pm 0.28 \%$ in series A, $3.19 \pm 0.09 \%$ in production series B and $3.34 \pm 0,17 \%$ in series C. At this stage, the highest content of total nitrogenous substances is observed in $\mathrm{A}$, then in $\mathrm{C}$ series, and the least in series B. At this stage there are no statistically significant differences in the content of total nitrogen in the three variants.

In the second phase of ripening the values of the total nitrogenous substances appear as:

$3.77 \pm 0.23 \%$ i.e. $4.19 \pm 0.05 \%$ and $3.74 \pm 0.33 \%$. At this stage there are statistically significant differences at the level of $p<0.05$. In the dry salting phase, a small increase in the nitrogen content is observed: in the production series $\mathrm{A}, 3.93 \pm 0.16 \%$ in $\mathrm{B}, 4.58 \pm 0.12 \%$ and in the cheeses of the third group C $4.17 \pm 0.33 \%$. There are statistically significant differences between the variants $A, B$ and $C$ in the dry salting phase and on the 20th day of ripening in brine in terms of the content of total nitrogenous substances. On the 45th day of ripening in brine, there are no statistically significant differences in the content of total nitrogenous substances between Bieno cheese and the cheeses produced through different technologies.

Analyzing the average values of the content of total nitrogenous substances, at the beginning and at the end of the examined ripening period, it is perceived that there is a tendency of slight increase up to the 20th day of ripening of the Bieno cheese, as a result of the different degree of nitrogen utilization from milk in the production, as well as a different degree of proteolytic decomposition. In the last phase of the 45th day of ripening, a minimal decrease in values is observed, which a result of the weaker proteolytic decomposition is probably due to: the higher percentage of salt in the cheese, the differences in the technology of making the cheese, the ripening conditions and the activity of microorganisms. The content of total nitrogenous substances increases quite slightly during the ripening in the three production series of Bieno cheese and ranges in the interval from $3.44 \pm 0.28 \%$ to $4.16 \pm 0.15 \%$ in $\mathrm{A}$, from 3.19 $\pm 0.09 \%$ to $4.11 \pm 0.15 \%$ in B and from $3.34 \pm 0.17 \%$ to $3.98 \pm 0.06 \%$ in C. The obtained results are similar to the results of the researches done by Mateva, (2004); Radevska, (2003); (Maćej et al., 2004). 


\section{DYNAMICS OF THE TOTAL NITROGEN}

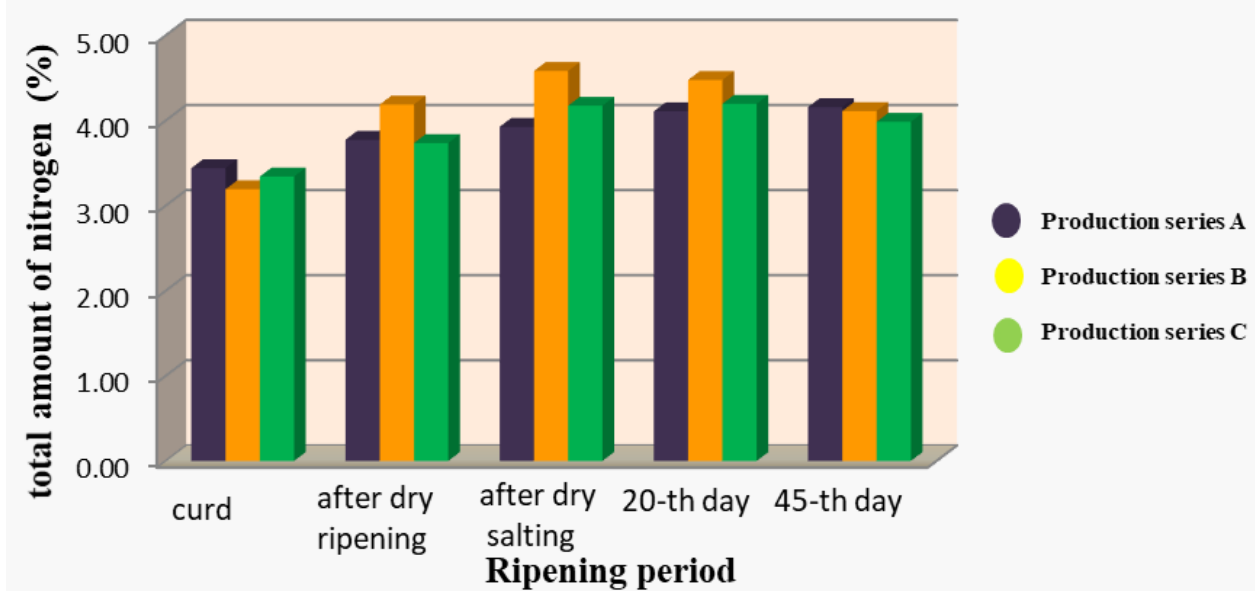

Figure 1: Dynamic of the total nitrogen during ripening period

The dynamics of the total protein content can be traced in the given tabular and graphical presentation in Table 2 and Figure 2.

Table 2: Dynamics of the total protein content in Bieno cheese

\begin{tabular}{|c|c|c|c|c|c|c|c|c|c|c|c|c|c|c|c|}
\hline & \multicolumn{5}{|c|}{ Cheese Series A } & \multicolumn{5}{|c|}{ Cheese Series B } & \multicolumn{5}{|c|}{ Cheese Series C } \\
\hline & $\bar{x}$ & $\min$ & $\begin{array}{c}\mathrm{ma} \\
\mathrm{x}\end{array}$ & $\mathrm{Sd}$ & $\mathrm{Cv}$ & $\bar{x}$ & $\min$ & $\begin{array}{c}\mathrm{ma} \\
\mathrm{x}\end{array}$ & $\mathrm{Sd}$ & $\mathrm{Cv}$ & $\bar{x}$ & $\min$ & $\begin{array}{c}\mathrm{ma} \\
\mathrm{x}\end{array}$ & $\mathrm{Sd}$ & $\mathrm{Cv}$ \\
\hline Curd & $\begin{array}{c}21,95 \pm \\
1.76\end{array}$ & $\begin{array}{l}19, \\
20\end{array}$ & $\begin{array}{l}24, \\
88\end{array}$ & $\begin{array}{c}2,2 \\
2\end{array}$ & $\begin{array}{l}10, \\
12\end{array}$ & $\begin{array}{c}20,36 \pm \\
0,55\end{array}$ & $\begin{array}{l}19, \\
52\end{array}$ & $\begin{array}{l}21, \\
31\end{array}$ & $\begin{array}{c}0,7 \\
1\end{array}$ & $\begin{array}{c}3,4 \\
9\end{array}$ & $\begin{array}{c}21,32 \pm \\
1,11\end{array}$ & $\begin{array}{l}19, \\
20\end{array}$ & $\begin{array}{l}23, \\
35\end{array}$ & $\begin{array}{c}1,5 \\
5\end{array}$ & $\begin{array}{c}7,2 \\
7\end{array}$ \\
\hline $\begin{array}{c}\text { After } \\
\text { ripening }\end{array}$ & $\begin{array}{c}24,08 \pm \\
1.45 \\
\end{array}$ & $\begin{array}{l}21, \\
37 \\
\end{array}$ & $\begin{array}{l}25, \\
97\end{array}$ & $\begin{array}{c}1,8 \\
2\end{array}$ & $\begin{array}{c}7,5 \\
7 \\
\end{array}$ & $\begin{array}{c}26,72 \pm \\
0,29 \\
\end{array}$ & $\begin{array}{l}26, \\
16 \\
\end{array}$ & $\begin{array}{l}27 \\
17 \\
\end{array}$ & $\begin{array}{c}0,3 \\
9 \\
\end{array}$ & $\begin{array}{c}1,4 \\
4\end{array}$ & $\begin{array}{c}27,38 \pm \\
0,98\end{array}$ & $\begin{array}{l}26, \\
41\end{array}$ & $\begin{array}{l}29, \\
47\end{array}$ & $\begin{array}{c}1,2 \\
9\end{array}$ & $\begin{array}{c}4,7 \\
0\end{array}$ \\
\hline $\begin{array}{c}\text { After } \\
\text { salting }\end{array}$ & $\begin{array}{c}25,05 \pm \\
0.99\end{array}$ & $\begin{array}{l}23 \\
60\end{array}$ & $\begin{array}{l}27, \\
24\end{array}$ & $\begin{array}{c}1,4 \\
1\end{array}$ & $\begin{array}{c}5,6 \\
4\end{array}$ & $\begin{array}{c}29,30 \pm \\
0,76\end{array}$ & $\begin{array}{l}28, \\
71\end{array}$ & $\begin{array}{l}31, \\
20\end{array}$ & $\begin{array}{c}1,0 \\
8\end{array}$ & $\begin{array}{c}3,6 \\
7\end{array}$ & $\begin{array}{c}27,65 \pm \\
0,50\end{array}$ & $\begin{array}{l}26, \\
41\end{array}$ & $\begin{array}{l}28, \\
39\end{array}$ & $\begin{array}{c}0,7 \\
5\end{array}$ & $\begin{array}{c}2,7 \\
2\end{array}$ \\
\hline $20^{\text {th }}$ day & $\begin{array}{c}26,20 \pm \\
0.58\end{array}$ & $\begin{array}{l}25, \\
20\end{array}$ & $\begin{array}{l}26 \\
85\end{array}$ & $\begin{array}{c}0,7 \\
1\end{array}$ & $\begin{array}{c}2,7 \\
0\end{array}$ & $\begin{array}{c}28,55 \pm \\
0,58\end{array}$ & $\begin{array}{l}27, \\
94\end{array}$ & $\begin{array}{l}29 \\
54\end{array}$ & $\begin{array}{c}0,6 \\
9\end{array}$ & $\begin{array}{c}2,4 \\
3\end{array}$ & $\begin{array}{c}27,03 \pm \\
0,28\end{array}$ & $\begin{array}{l}26, \\
54\end{array}$ & $\begin{array}{l}27 \\
37\end{array}$ & $\begin{array}{c}0,3 \\
6 \\
\end{array}$ & $\begin{array}{c}1,3 \\
4\end{array}$ \\
\hline 45th day & $\begin{array}{c}26,53 \pm \\
0.93\end{array}$ & $\begin{array}{l}25, \\
26\end{array}$ & $\begin{array}{l}28, \\
33\end{array}$ & $\begin{array}{c}1,2 \\
3\end{array}$ & $\begin{array}{c}4,6 \\
3\end{array}$ & $\begin{array}{c}26,21 \pm \\
0,72\end{array}$ & $\begin{array}{l}25, \\
26\end{array}$ & $\begin{array}{l}27, \\
30\end{array}$ & $\begin{array}{c}0,9 \\
0\end{array}$ & $\begin{array}{c}3,4 \\
5\end{array}$ & $\begin{array}{c}25,48 \pm \\
0,49\end{array}$ & $\begin{array}{l}24 \\
88\end{array}$ & $\begin{array}{l}26, \\
41\end{array}$ & $\begin{array}{c}0,6 \\
1\end{array}$ & $\begin{array}{c}2,4 \\
1\end{array}$ \\
\hline
\end{tabular}

$\mathrm{F}_{0,05}=3,88 \mathrm{p}<0,05$

$\mathrm{F}_{0,01}=6,93 \mathrm{p}<0,01$

Observing the results regarding the amount of total proteins in the three production series, it can be noticed that the curd from the production series A has $21.95 \pm 1.76 \%$, the cheese from series B has $20.36 \pm 0.55 \%$ and in the last group ranges from $21.32 \pm 1.11 \%$.

In the second stage of ripening the values of total proteins are the following: $24.08 \pm 1.45 \%, 26.72 \pm 0.29 \%$ and $27.38 \pm 0.98 \%$ where statistically significant differences are observed such as $(\mathrm{p}<0.05)$.

In the dry salting phase, a small increase in the content of total proteins is observed: in production series $\mathrm{A}$, $25.05 \pm 0.99 \%$, production series $B, 29.30,760.76 \%$ and in production series $C, 27.65 \pm 0.50 \%$. On the 20 th day of ripening in the cheeses from groups $\mathrm{A}, \mathrm{B}$ and $\mathrm{C}$ the following values were determined: $26.20 \pm 0.58 \% ; 28.55 \pm 0.58 \%$ and $27.30 \pm 0.28 \%$. In the phase of dry salting and on the 20th day of ripening in brine there are statistically significant differences in the content of total protein in Bieno cheese, while on the 45th day of ripening in brine, according to studies, the total protein content is: $26,53 \pm 0.93 \%, 26.21 \pm 0.72 \%$ and $25.48 \pm 0.49 \%$. At this stage there are no statistically significant differences in the content of total nitrogen in Bieno cheese. In the last stage, on 
the 45th day of ripening, there is a slight decrease in values, which is probably due to proteolysis, higher percentage of salt and differences in technology, as well as the activity of microorganisms.

\section{DYNAMICS OF THE TOTAL PROTEINS}

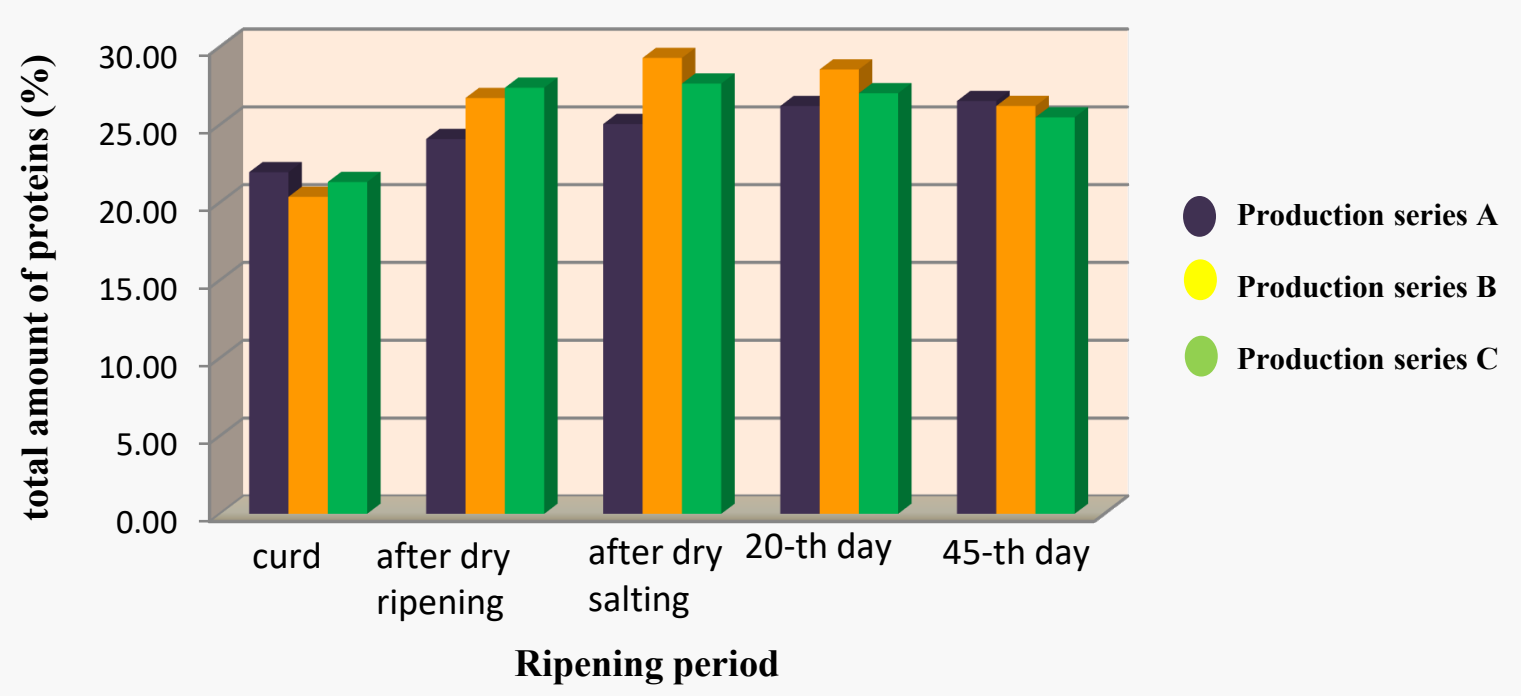

Figure 2: Dynamic of the total proteins content during ripening period

Monitoring the values of total proteins at all stages of ripening, from the beginning to 45 days of ripening, it is perceived there is an increase of total proteins by $22.50 \%$ in the production series $\mathrm{A}, 28.73 \%$ in the series B cheeses and $16.69 \%$ in the production series $\mathrm{C}$. The results obtained regarding the total proteins are slightly higher than the results of (Mateva, 2004), but are similar to the results obtained in the analyses by (Radevska et al., 2003) for the total proteins in Bieno cheese, with the results of Martinovic, (2016); Špoljarić, (2015); Vranković, (2020).

\section{CONCLUSIONS}

Based on the obtained results, it can be observed that the content of total nitrogenous substances during ripening tends to increase slightly until the 20th day due to the different degree of utilization of nitrogenous substances from milk and the degree of proteolytic decomposition. In the last stage of ripening, a minimal decrease in values has been distinguished which is probably a result of the reduced proteolytic decomposition due to the higher percentage of salt, the differences in the technology of cheese preparation, the ripening conditions, as well as the activity of microorganisms. The highest percentage of nitrogenous substances, and thus of total protein, is found in the cheeses of the production series $\mathrm{A}$.

It can also be concluded that the volume of proteolysis is affected by the type and amount of enzyme, the temperature during the ripening of the cheese, the length of ripening and the activity of the enzymes. The technological process of production, in essence, greatly affects the dynamics and breakdown of proteins, which is confirmed by our research.

\section{SOURCES OF FUNDING}

This research received no specific grant from any funding agency in the public, commercial, or not-for-profit sectors.

\section{CONFLICT OF INTEREST}

The author have declared that no competing interests exist. 


\section{ACKNOWLEDGMENT}

None.

\section{REFERENCES}

[1] Baltadzieva Marija, TehnologiЯ na mlecnite produkti, SofiЯ Bulgaria. 1993, 43-47.

[2] Cvetanović Snežana, Nikolić D., Đorđević B., Miletić I., Stanković I., Vidović B., Ispitivanje belih sireva u salamuri sa teritorije pirotskog okruga, Prehranbena industrija (1-2), 2008, 88-91.

[3] Dozet Natalija, Stanišić M., Sumenić S., Izučavanje novih tipova sireva na bazi autohtone tehnologije, Mljekarstvo, 1974, 24 (10), 224-231.

[4] Jovanovich Snezana., Macej O., Barac M., Vucic T., Jovanovic Z., Proteoliticke promene tokom zrenja polutvrdog sira proizvedenog na bazi koagegata protein mleka, Prehrambena industrija, 2007 1-2, (26).

[5] Mateva, Dubrova N., Changes in proteins during ripening of Bieno cheese caused by proteolityc enzymes, Msc Thesis, University "St. Cyril and Methodius"- Skopje, Faculty of Agricultural Sciences and Food, North Macedonia, 2004.

[6] Mastrigt Van Oscar, Tejeda D., Kristensen M., Abee T., Smid E, Aroma formation during cheese ripening is best resembled by Lactococcus lactis retentostat cultures, Microb Cell Fact, 2018, 17:104, 2-8.

[7] Martinović, Slaviša, Primjena mliječnih proteina u prehrambenoj industriji, Undergraduate thesis, Josip Juraj Strossmayer University of Osijek, Faculty of Food technology, 2016

[8] Mačej O., Jovanović S., Seratlić S., Barać M., Fresh cheese production on the basis of milk-protein conggregates, Biotechnology in Animal Husbandry, 20 (1-2), 2004, 119-129

[9] Radevska B., Mitrevska L., Srbinovska S., Uticaj kvaliteta sirovog mleka na standardnog proizvodnju autohtonog sira „Bieno Sirenje,, u IMB „, Mlekara,, Bitola, Prehrambena industrija 1-2, vol.14, 2003.

[10] Vranković, Lucija, Određivanje udjela ukupnih mineralnih tvari i proteina u uzorcima sireva, Undergraduate thesis, University of Zagreb, Faculty of Food Technology and Biotechnology, 2020.

[11] Van Sluke, L.L., Price, W.V., Cheese, Orange judd publishing, New York, 1952.

[12] Špoljarić Maja, Primarna prerada mlijeka i proizvodnja svježeg sira u mljekarama srednjeg kapaciteta, Završni rad, Sveučilište Josipa Jurja Strossmayera u Osijeku Prehrambeno - Tehnološki fakultet, Osijek, 2015. 